\title{
Antecedents of union loyalty: the influence of individual dispositions and organizational context
}

\author{
RODERICK D. IVERSON \\ Department of Management and Industrial Relations, University of Melbourne \\ SAROSH KURUVILLA \\ New York State School of Labor and Industrial Relations
}

\begin{abstract}
Summary
Previous research has consistently found relationships between union loyalty and the antecedent variables of demographics, job related variables, and union related variables. However, little or no research has investigated the relationship between union loyalty and individual dispositions and organizational context. The purpose of this study was to test a causal model which evaluated the influence of individual dispositions and organizational context in predicting union loyalty controlling for the effects of demographics, job related, and union related variables. Contextual data were collected from 405 schools and matched with union loyalty and other attitudinal data from 838 public school teachers in a large U.S. Midwestern city. The LISREL results indicate that the individual dispositions of positive and negative affectivity and the contextual variables of attendance rate, school type, race homogeneity and socio-economic status had significant total causal effects on union loyalty. Implications of these findings are discussed.
\end{abstract}

\section{Introduction}

Previous research on the antecedents of union commitment has identified a number of different antecedents of union commitment, such as demographics (e.g. age, gender, education, kinship responsibility), job related factors (e.g. stress, autonomy, distributive justice), union related factors (previous union experience, union socialization, exposure to union information), and employee orientations (e.g. job satisfaction, organizational commitment, union satisfaction) (e.g. Barling. Fullagar and Kelloway, 1992; Deery, Iverson and Erwin, 1994; Gallagher and Clark, 1989; Fullagar and Barling, 1989, 1991; Kuruvilla, Gallagher and Wetzel, 1993; Kuruvilla and Iverson, 1993).

In this paper, we propose to extend research on the antecedents of union commitment by examining the effect of individual dispositions and the organizational context on union commitment. 
The relative lack of attention to individual dispositions (e.g. personality traits) and organizational context (e.g. situational and environmental factors) as determinants of union commitment is surprising, given that these variables influence both the attitudes and behavior of individuals. In the case of individual dispositions, there is a recent and growing literature that suggests that these traits have fundamental impacts on employee attitudes. For instance, Agho, Mueller and Price $(1992,1993)$ found that employees who are predisposed to experience discomfort (also called negative affectivity) are more likely to dislike their jobs relative to employees who are predisposed to be generally happy (also called positive affectivity). In fact, the expanding research literature suggests that dispositional factors are primarily responsible for the temporal stability and cross-situational consistency of job satisfaction results (Agho et al., 1992, 1993; Levin and Stokes. 1989). These results appear consistent with the views of Schneider (1987) who argued that 'the attributes of people, not the nature of the external environment, or organizational technology or organizational structure, are the fundamental determinants of organizational behavior' (p. 437). Given that job satisfaction has been found to be a central determinant of union commitment (e.g. Fullagar and Barling, 1989; Kuruviila et al., 1993). It appears reasonable to investigate whether individual dispositional variables would affect union loyalty via their effects on job satisfaction.

Similarly, there is a large and growing literature regarding the impact of contextual factors (e.g. structure, role characteristics, organizational climate) on employee attitudes and orientations (e.g. job motivation, job satisfaction), although this literature has not significantly informed research on union commitment. These factors are generally termed 'situational factors' in the literature, and include factors specific to the job or job characteristics (e.g. job autonomy, complexity, job structure) as well as 'environmental' factors such as job context and organizational climate (Arvey, Carter and Buerkley, 1991; Price and Mueller, 1986b). Arvey et al. (1991) in their review of situational determinants of job satisfaction note that the literature contains several studies that have used both subjective and objective measures of context in examining attitudes.

We draw from this literature to guide the selection of both subjective and objective variables in our model. We also draw from studies that focused specifically on school districts such as Ostroff (1992), who found that specific contextual factors such as age of the school building, and teacher/student ratios have significant influences on teacher satisfaction and school performance.

This paper argues that in U.S. school districts, contextual variables are likely to have critical influences on both the jobs (and therefore job satisfaction) of teachers, as well as on labor management relations. For instance, wage and workload negotiations between teachers unions and school district 
management is constrained by the wealth of the community and school district finances. The location of the school and the type of students also significantly impact the job satisfaction of teachers. Given the large amount of influence that American teachers unions have on decisions regarding teachers wages and workloads, contextual factors are likely to affect union commitment as well.

The goal of this paper is to examine the effect of individual dispositional variables and organizational context variables on union commitment, controlling for other determinants found in the literature. Aside from measures of positive and negative affectivity, in this study we use several new objective structural and contextual variables such as school setting, school finances, student type, and racial composition from 405 schools in the U.S.

Given that the construct of union commitment is a multidimensional one, and that the dimension of union loyalty (i.e. degree of pride and instrumentality in the union) has been found to account for most of the variance in union commitment (e.g. Gordon, Beauvais and Ladd, 1984; Gordon, Philpot, Burt, Thompson and Spiller, 1980) and is regarded as the most stable dimension (Fullagar and Barling, 1989), union loyalty is used as the dependent variable in this paper.'

The following section briefly discusses the nature of labor-management relations in U.S. school districts in order to provide a contextual description. Next, we discuss briefly the relevant literature and development of a causal model of union loyalty, while later sections deal with data and methods. Following this, the results are presented and a new revised causal model is developed.

\section{The context: labor relations in U.S. school districts}

Over 70 per cent of America's public school teachers are members of unions (Tucker, 1991; Register and Grimes, 1991). They are affiliated with either the American Federation of Teachers (AFT) or the National Education Association (NEA), one of the largest unions in the United States with over 1.6 million members. Over the years, these two unions have become powerful organizations with considerable political influence and bargaining power. Tucker (1991) notes that teachers union members often sit in state legislatures, often serving on powerful education committees, and the NEA encourages its members to run for local school board elections. Via this kind of political activity, Tucker (1991) suggests that teachers unions have had considerable bargaining successes. For instance, since 1983, teacher salaries have increased by 51 per cent, far higher than inflation rates. Due to their success in collective bargaining, teachers have gained a greater voice in many district and school decisions, job protection, and substantial protection against arbitrary management decisions. Crisci and Shadow 
(1988) suggest that given powerful teachers unions, there has been significant erosion in management rights regarding terminations, transfers, and assignments.

Consequent to the publication of the report on America's schools (A Nation at Risk-USA, 1984), public outrage about the way children are learning has focused attention on teachers unions as being a key obstacle against effective reforms. Labor relations in school districts are largely described as being adversarial (Wishnick and Wishnick, 1993). In addition, Crisci and Shadow (1988) note that contracts have become increasingly detailed and work rules have prompted a certain inflexibility in school management that affects the delivery of education in significant ways. Smith (1989) suggests that the presence of a unionized labor force has been a contextual constraint on the school district's ability to be innovative and to adapt to environmental change.

Under severe attack from the public, teachers unions have either resisted management efforts to regain control, or, in other cases, have begun to cooperate with management for improvement (Katz and Kochan, 1991), via strategies such as teacher empowerment (Geisert, 1992). There is some evidence that teachers are loyal union members. Hammer and Wazeter (1993), for example, suggest that the 'union mentality' of teachers and responsive leadership were critical determinants of overall union effectiveness. In the context of an adverse environment of shrinking budgets and finances, public distrust, and pressures on various related resources, contextual variables are likely to gain in importance in the job satisfaction and union loyalty of teachers, rather than diminish. It is against this background that our study is conducted.

\section{Labor-management relations in the research setting}

The labor relations in the public school system from which this sample is drawn appears to be consistent with the general picture of labor relations outlined above. In 1916 the union became one of the first local chapters in the nation to be chartered by the AFT. However, it was the contract of 1967 that reflected the extent of union involvement in school decision making. The 1967 contract first opened the door to greater union participation over decisions regarding school operations and policy that has since then developed and increased over subsequent contracts.

Management prerogative is reported to have slowly diminished since 1967. Over the last two decades, work rules have become more rigid, and many work rule provisions of the 1967 contract are still in effect today. The definition of grievance in the contract is broad and all-encompassing, including changes from past practice or policy. In addition, matters concerning the curriculum, such as the 
program for teaching children to read are written into the contract so that any proposed changes have to be tabled at the time of negotiating new contracts. Apart from generous terms and conditions of service, the contract also specifies that several contextual variables impinging on teachers job performance, such as class size, the type of architecture of certain classrooms, the number of substitute teachers and their recruitment, are subject to collective bargaining.

\section{The causal model of union loyalty}

The causal model of union loyalty is presented in Figure 1, and the definitions of the variables are contained in Table 1.

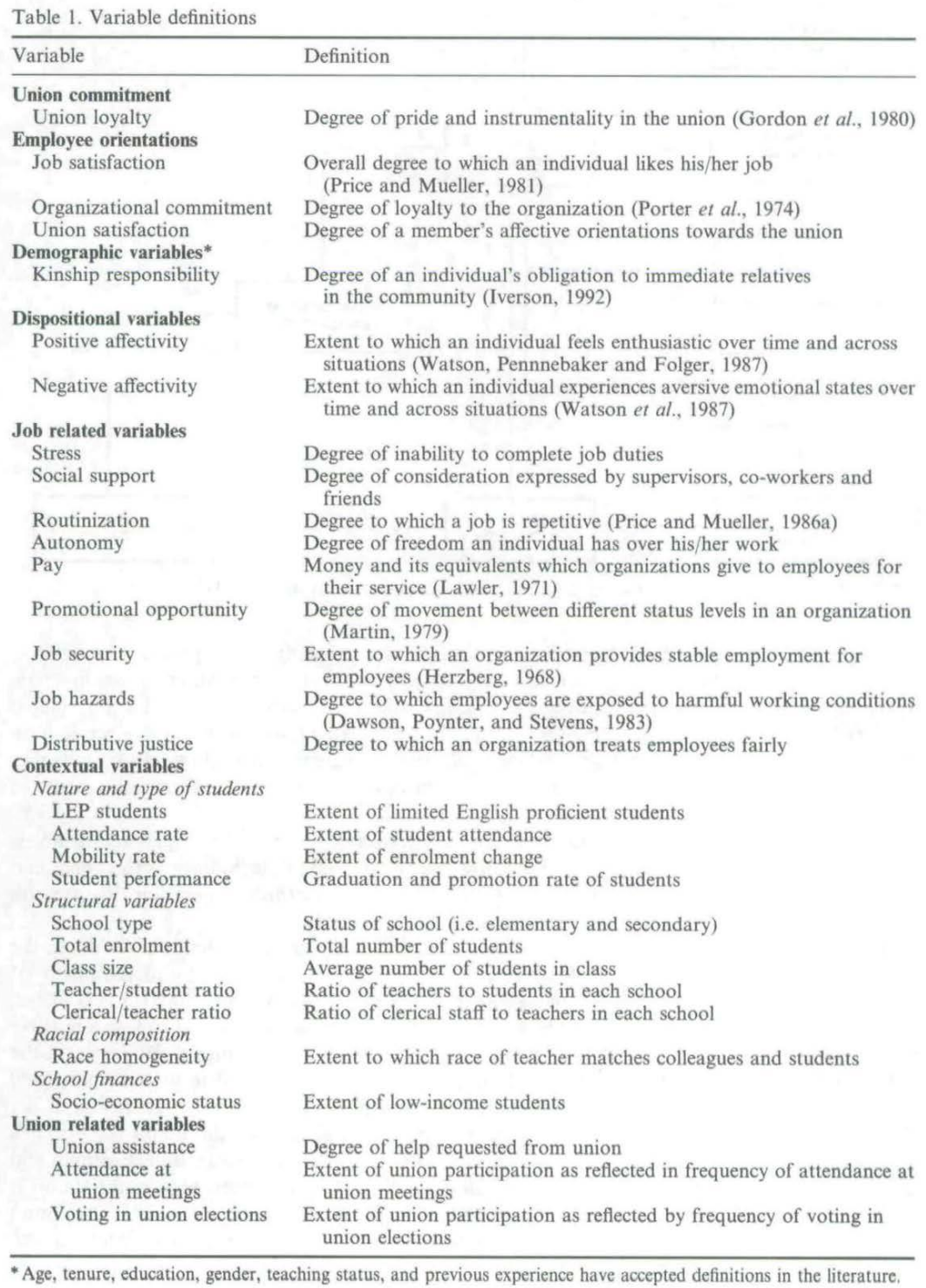


In developing our causal model, we are guided by previous research regarding the determinants of union loyalty, and the current literature regarding dispositional and contextual variables. Given that there exists a plethora of studies that have examined the impact of demographic variables (i.e. age, tenure, education, gender, teaching status, previous experience, and kinship responsibility), job related factors (i.e. stress, support, routinization, autonomy, pay, promotional opportunity, job security, job hazards, and distributive justice) and union related factors (i.e. union assistance, attendance at union meetings and voting in union elections) on employee loyalty to the union (e.g. Barling et al., 1992; Fullagar and Barling, 1989; Gallagher and Clark, 1989; Kuruviila et al., 1993), we do not discuss these in detail, and refer the reader to those studies.

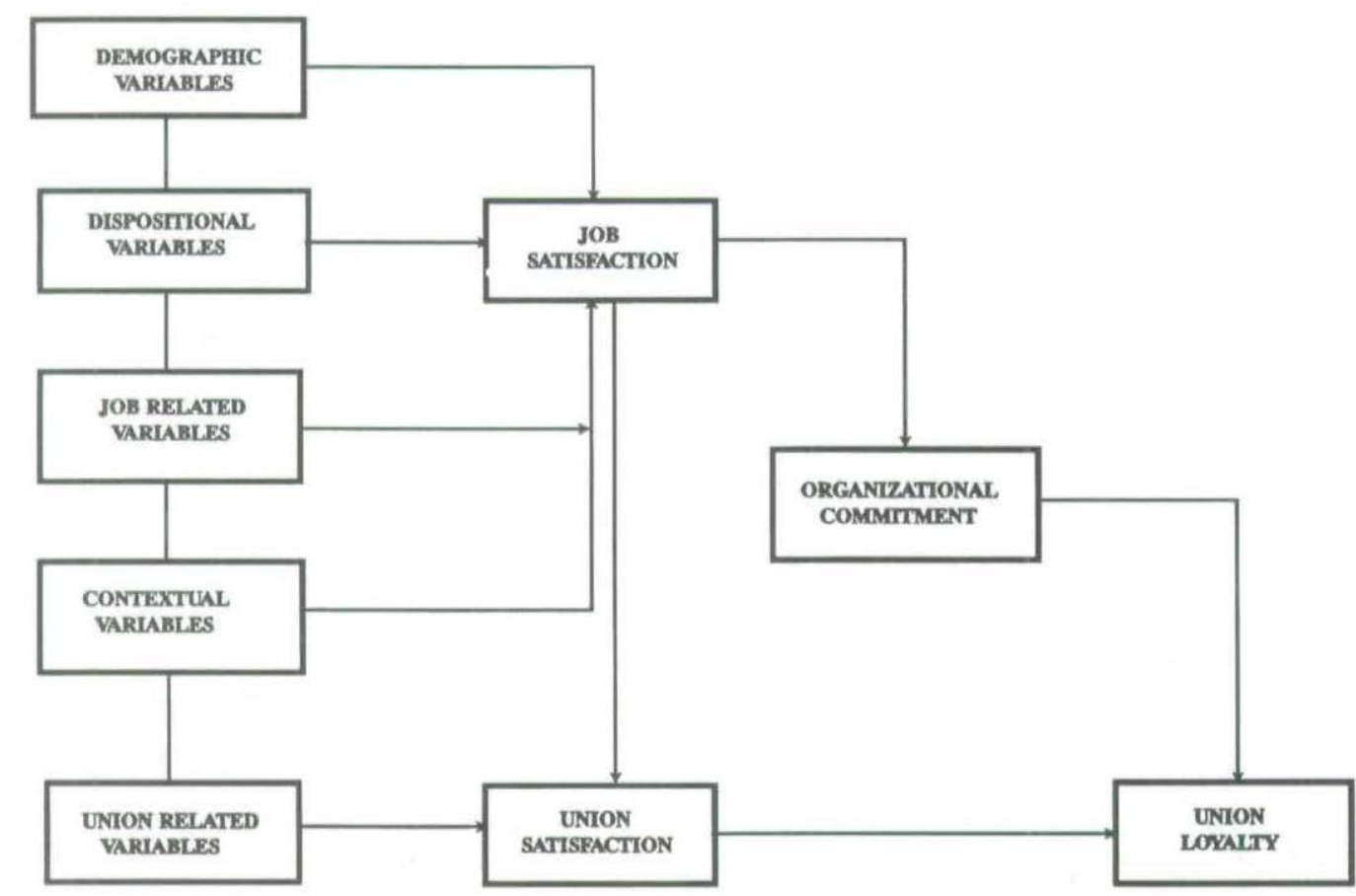

Figure 1. The antecedents of union loyalty

The logic of our model is that union loyalty is determined by several endogenous variables, which in turn are determined by a number of exogenous variables, including dispositional and contextual factors. The three endogenous variables that determine union loyalty are job satisfaction, organizational commitment, and union satisfaction.

The relationships between these variables are complex, as the previous literature shows. In the organizational literature, job satisfaction has been found to be the major determinant of organizational commitment (see Iverson and Roy. 1994; Mowday, Porter and Steers, 1982; Mueller, Boyer, Price and Iverson, 1994; Price and Mueller. 1986a), hence we propose a positive causal path from job satisfaction 
to organizational commitment in the model. However, in the union commitment literature, job satisfaction has previously been found to be both positively and negatively related to union commitment (see Gordon et al., 1980, 1984; Kuruvilla et al., 1993). If employees are dissatisfied with their jobs, they will turn to the union for possible redressal or alleviation of their problems e.g. they will 'voice' their dissatisfaction (Freeman and Medoff, 1984) and hold the union accountable for job-related outcomes. Hence, the union is evaluated favorably or unfavorably based on those outcomes. Kuruvilla et al. (1993) also found that union satisfaction is an antecedent of union commitment. Since the teachers union has co- decision-making power in respect of various work conditions in this school district, and is seen to be instrumental by the teachers, we hypothesize that job satisfaction and union satisfaction will be positively correlated. It is our expectation that teachers will attribute reasons for good job satisfaction to both the union and management. Consequently, causal paths lead from job satisfaction to organizational commitment and from union satisfaction to union loyalty in our model. It seems reasonable to expect that given the decision making authority allocated to labor unions, that organizational commitment and union loyalty will also be positively correlated (some researchers, such as Angle and Perry (1986). refer to this positive correlation as dual commitment).

With regard to the exogenous variables, we discuss below the dispositional and contextual variables, drawing on the few studies that have examined some of these factors. As noted there, the effect of these variables on union loyalty has not been examined before in the literature, although there are a few studies that have relevance for the selection of variables in our model.

We draw from the expanding body of research that has examined dispositional factors influencing job satisfaction, (e.g. Agho et al., 1992. 1993; Arvey et al., 1991; Levin and Stokes, 1989) in specifying our model. There is also increasing support for the use of dispositional variables in the literature for other organizational outcomes. Judge (1993), for example, found negative affectivity to interact with job satisfaction to predict turnover, while Iverson. Olekalns and Erwin (1994) reported positive affectivity to have a negative impact on absenteeism behavior. This body of research, which Arvey et al. (1991) call the specified person effects model in their review of job satisfaction determinants, has unearthed several dispositional factors related to job satisfaction. As Arvey et al. (1991. p. 360) note 'a particularly promising area of research entails the examination of positive and negative affectivity on job satisfaction. These are basic, pervasive personality dimensions which arise repeatedly in measures designed to tap a variety of personality constructs and which are strongly related to major dimensions of mood'. 
Specifically, in examining the effects of positive and negative affectivity, several studies have examined these variables in relation to job satisfaction (e.g. Brief. Burke. George. Robinson and Webster, 1988; Judge and Hulin. 1993; Watson and Clark. 1984; Levin and Stokes, 1989). One clear finding is that the stability of job attitudes across time and situations depends largely on dispositional factors such as positive and negative affectivity (Pulakos and Schmidt, 1983; Staw and Ross, 1985).

Therefore, dispositional variables not only influence attitudes directly, but they account for the stability of attitudes over time and situations, and they also explain attributions. From the findings of Deery, Iverson and Erwin (1992), it is possible to suggest that teachers who feel enthusiastic over time and across situations would exhibit greater union loyalty relative to teachers who experience adverse emotional states. As Levin and Stokes (1989) note, job related information is distorted to be consistent with a teachers' affective state. In this case, the union will be seen as instrumental for both favorable and unfavorable job attributes, if the union is significantly involved in decision making on those job attributes. Despite the large number of dispositions being currently studied, in this study, we use the most common measure of dispositions, that of positive and negative affectivity. Consistent with previous research on the effect of dispositional factors, we posit that teachers with high scores on positive affectivity will evidence higher levels of loyalty to the union via job satisfaction. Conversely, teachers with high scores on negative affectivity are anticipated to display lower levels of union loyalty, also via job satisfaction.

Although there are relatively few studies that have examined the impact of contextual variables on school teachers' attitudes and behaviors, there is a much larger literature on the effect of contextual variables such as technology, structure, role dimensionality and clarity, and organizational culture on organizational outcomes (see Locke (1976) for a comprehensive review of these factors). In particular, the job satisfaction literature has examined the effect of various situational and environmental variables on job satisfaction. Arvey et al. (1991) review this literature in more detail and identify several contextual variables that affect job satisfaction, in particular, the effects of organizational climate. Since these studies have clearly established the importance of studying the organizational context, we rely on their findings to posit our general hypothesis that contextual variables will indirectly influence union loyalty via their effects on job satisfaction.

We also use specific studies of school teachers (e.g. Metropolitan Life Survey (MLS), 1985, 1989; Ostroff, 1992) in the selection of contextual variables germane to school teachers' jobs. These include factors such as the nature and type of students at the school, the students' attendance and mobility rates, class sizes, teacher/student ratios, teacher/clerical ratios, and race of teachers and 
students. Regarding the nature and type of student variables, we hypothesize that the higher the ratio of limited English proficiency (LEP) students, and the higher the student transfers in and out of the school (mobility rate), the lower the job satisfaction of teachers. It is anticipated that high student attendance rates and student performance scores will be positively related to a teacher's job satisfaction.

Our hypotheses regarding structural variables are drawn from the literature on the effects of structural features on employee attitudes and behaviors (see Mowday et al., 1982; Price and Mueller. 1986b). as well as on some studies that have examined school teachers in particular. A number of studies have shown that teachers in high schools face more problems of large class sizes, and student discipline, that critically affect teacher performance (MLS, 1985). Therefore, we expect that high school teachers will exhibit lower job satisfaction than elementary school teachers. Schools with higher enrolment invariably have larger class sizes and increasing pressures on resources. Given that larger class sizes, low teacher/student ratios and low clerical/ teacher ratios significantly impact both on the workload and teaching effectiveness of the teacher (MLS, 1989), it is hypothesized that these will lower a teacher's job satisfaction, and consequently their loyalty to the union.

We also include a prediction connected with the racial context of the school and school district. The racial composition of the teachers in the sample exhibits some diversity with 56 per cent of them being White, 31 per cent African American, 8 per cent Hispanic, 3 per cent Asian, and 2 per cent consisting of other diverse races. Several studies such as Tsui, Egan and O'Reilly (1992) and Tsui and O'Reilly (1989) have shown that the racial composition of the organization has important attitudinal and behavioral consequences for individuals. Tsui et al. (1992) suggest that the degree of racial difference between an individual and his or her social unit is an important relational concept. Their argument is that individuals who are not socially integrated wilt be less attitudinally attached to the organization (Tsui et al., 1992). Another view on the effects of race can be found in the work of Hogg and Abrams (1988). They use social identity theory to argue that those in social groups characterized by higher power, prestige, and status, will exhibit different attitudes and behaviors due to their greater need to maintain their identity than others.

Based on these studies, and given the importance of normative variables in influencing attitudes (Fishbein and Ajzen, 1975), we posit that the racial composition within a school does matter in explaining their loyalty to the union. Specifically, we suggest that teachers will exhibit greater job satisfaction, resulting in greater loyalty to the union when they have colleagues and students of the same race as themselves. It is important to note that this hypothesis needs to be viewed with some 
caution, since we are unable to explain, in this study, the reasons for the different racial composition in this school district. We do not have, for instance, any data on aspects such as the access to power for the different races of the school system (e.g. might White teachers in a mainly African-American school environment differ from African-American teachers in a mainly White school environment). Yet, the previous results in respect of racial composition are compelling enough for us to examine the effects of this variable.

Given that school finances critically impact not only the quality of students in the school (Gottfredson and Gottfredson, 1985; MLS, 1989), but also the teacher's working conditions, student performance, and teacher satisfaction, and given that the union has some influence regarding workloads and working conditions, we expect a relationship between school district finances and teachers attitudes towards their unions. Specifically, we posit that teachers in schools with students from a lower socio-economic status will evidence higher loyalty towards their unions (Coleman, Campbell, Hobson, McPartland, Mood, Weinfield and York, 1966).

In sum, the brief literature review above suggests several sets of dispositional and contextual variables that are pertinent to this study. Specifically, dispositional variables appear to significantly determine an individual's emotional state of mind regarding his or her attitudes to work. Although the previous research has found that most of these variables affect teacher performance and job satisfaction, our rationale for expecting links to union loyalty in this paper centers around the role that the unions have in deciding many of these issues. In terms of contextual variables, class size, workloads, staffing issues (teacher/clerical staff ratios), other working conditions, and school finance expenditures are all subject of collective bargaining in this school district, and teachers are likely to see the union as being instrumental in making improvements in these contextual situations.

\section{Method}

Research setting and sample

The site for this research was a large urban public school district located in a major city in the Midwestern United States. The school district comprises approximately 600 elementary and secondary schools, with around 24,000 teachers, and nearly 400,000 students.

The sample consisted of 838 regular certified and full-time-basis substitute teachers selected from personnel records during the Winter of 1991. The teachers were all classroom teachers, that is, 
they were professional staff members who instructed students. The sample did not include administrators (e.g. principals) or ancillary staff (e.g. teacher's aid, nurses or welfare officers) which were either not qualified or certified to teach, or who did not directly instruct students. Seventy-nine per cent of the sample were female, with 83 per cent being elementary teachers. The average age, tenure, and education were 38.3 years $(S . D .=9.3), 4.4$ years $(S . D .=3.7)$, and 17.3 years $(S . D .=1.1)$, respectively. Chi-square analysis was undertaken to evaluate the representativeness of the sample, Data for the population were obtained from the school district records. There were no gender differences between the population and sample $\left(X^{2}(1)=1.86, p>0.05\right)$. Since the teachers were drawn from the elementary and high schools to create an aggregated sample, the statistical technique known as the Chow test (Gujarati, 1978) was employed to test whether the sample populations from the elementary and high schools were significantly different. No consistent pattern of differences was found for the endogenous variables of job satisfaction, organizational commitment, union satisfaction and union loyalty, confirming the aggregation of the two subgroups was appropriate.

\section{Data collection}

Using the personnel records of the school district, 1500 teachers were randomly selected to be surveyed. Respondents were informed that participation was voluntary and all information collected was confidential. The questionnaire was accompanied by an answer sheet with an identification number for follow-ups which was electronically scanned. Questionnaires were mailed to teachers at their schools in early January 1991. A total of 838 (from 405 different schools) were returned by the close-out date, representing a corrected response rate of 57 per cent. In addition, contextual variables were obtained from the records of the State Board of Education 1989-1990 school year report card, as well as the Racial/Ethnic Survey prepared by the staff of the department of Research, Evaluation and Planning of the school district. The contextual variables thus obtained were matched with the 405 schools in our survey.

\section{Measurement}

Our measures include several dispositional and contextual variables which are discussed in greater detail below, and several variables that have been found to influence union loyalty in previous research. 
In relation to reliability, coefficient alpha (unstandardized) was used to estimate the reliability of the multiple-item measures. "When a variable was measured by only two items, the reliability was assessed by KR-20 (Kuder-Richardson-20). The zero-order correlations between the measures are presented in Table 2. As LISREL VII (Jöreskog and Sörbom, 1988) was the main technique used in the analysis, we first had to satisfy the measurement model before progressing to the structural model (Anderson and Gerbing, 1988). The convergent and discriminant validity of the model was supported (see Bagozzi and Yi (1988) for recommended procedures), where the normed comparative fit index (CFI) (Bentler, 1990) was an acceptable 0.96.

The measures of the variables below (apart from union satisfaction, the demographic variables, the union related variables of union assistance, attendance at union meetings, and voting in union elections and the contextual variables) were composed of multiple items. Where otherwise noted in the section, all items used a five-point Likert-type scale ranging from strongly disagree (1) to strongly agree (5). Established measures were also employed where possible.

\section{Endogenous variables}

\section{Union loyalty}

The four factors of union commitment were assessed using 11 items from the Gordon et al. (1980) scale. Confirmatory factor analysis found that the best fitting model was obtained for the four-factor model of union commitment, where union loyalty was the most important factor, explaining 40 per cent of the total variance in union commitment. As these results are consistent with other studies (e.g. Fullagar and Barling, 1989; Gordon et al., 1984), we focus on the component of union loyalty (three items: $M=3.13$, S.D. $=0.89$, alpha $=0.83$ ) in our analysis.ii 


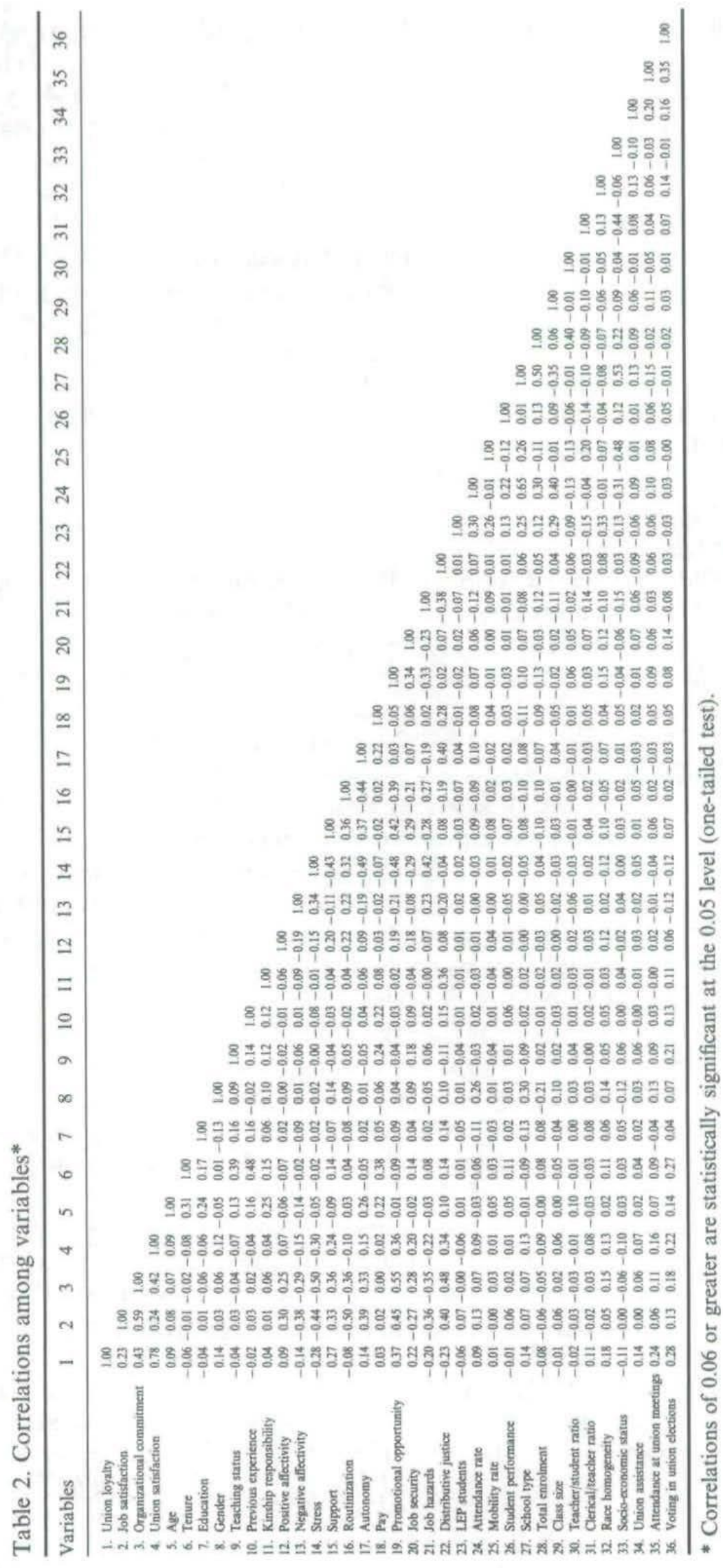




\section{Job satisfaction}

The scale of job satisfaction (four items: $M=4.08, S . D .=0.68$, alpha $=0.77$ ) was operationalized by an adaptation of the established scale by Brayfield and Rothe (1951).

\section{Organizational commitment}

The scale of organizational commitment (four items: $M=3.39, S . D .=0.74$, alpha $=0.72$ ) was measured using a shortened scale by Porter, Steers, Mowday and Boulian (1974).

\section{Union satisfaction}

The scale of union satisfaction was formulated by the researchers and was measured by a single item 'I am quite satisfied with my union' (one item: $M=3.11$, S.D. $=1.04$ ).

\section{Exogenous variables}

\section{Demographic variables}

The demographics of age (in years), tenure (in years), education (in years), gender (coded 1 for females and 0 for males), teaching status (coded 1 for regular certified and 0 for full-time-basis), and previous district experience (coded 1 for yes and 0 for no) were measured by single items. Kinship responsibility (which measures a composite of marital status, number of dependents, and the proximity of relatives, where the possible range was low (0) and high (4)) (three items: $M=2.56, S . D .=1.28$ ) was measured using the scale by Blegen, Mueller and Price (1988).

\section{Dispositional variables}

Positive affectivity (three items: $M=4.07$. S.D. $=0.58$, alpha $=0.61$ ) and negative affectivity (three items: $M=2.64$. S.D. $=0.84$, alpha $=0.73$ ) were measured by an adaptation of the Multidimensional Personality Index obtained from David Watson (see Agho et al, 1992, 1993). 


\section{Job related variables}

The scale of stress (11 items: $M=2.75$, S.D. $=0.58$, alpha $=0.76$ ) measured the psychological symptoms of stress by focusing on the aspects of role ambiguity, role conflict, work overload, and resource inadequacy from the scales of Kahn, Wolfe, Quinn, Snoek and Rosenthal (1964), Rizzo, House and Litzman (1970), and Caplan, Cobb, French, Harrison and Pinneau (1975). Social support (eight items: $M=$ 3.74$, S.D. $=0.58$, alpha $=0.73)$ evaluated the consideration expressed by the supervisors, co-workers, and friends using a modification of House's (1981) measure. The scales of routinization (three items: $M=$ 2.09, S.D. $=0.67$, alpha $=0.64$ ) and autonomy (three items: $M=3.36, S . D .=0.82$. alpha $=0.60$ ) were operationalized by modified measures by Price and Mueller (1986a) and Tetrick and LaRocco (1987), respectively. Pay was assessed by a single question $(M=\$ 26652, S . D .=\$ 5376)$ asking respondents their total yearly income at the present time from the district before taxes and other deductions are made. Following the recommendations of Parker and Fenwick (1983), Pareto curve estimate for the final openended pay category was computed. The four variables of promotional opportunity (three items: $M=$ 3.45, S.D = 0.81, alpha =0.69), job security (three items: $M=3.68, S . D .=0.78$, alpha =0.64), job hazards (three items: $M=2.72$, S.D. $=0.93$. alpha $=0.67$ ), and distributive justice (three items: $M=2.86, S . D .=$ 1.04 , alpha $=0.83)$ were assessed by scales of Price and Mueller (1981), Oldham, Kulik, Stepina and Ambrose (1986), the researchers, and Price and Mueller (1981, 1986a), respectively.

\section{Contextual variables}

The contextual variables were obtained from records of the State Board of Education 1989-1990 school year report card and the Racial/Ethnic Survey:Staff prepared by the Department of Research, Evaluation and Planning of the school district and include the following.

Nature and type of students A number of measures were used to capture this contextual aspect.

(a) LEP students (coded as the number of limited English proficient students divided by total enrolment multiplied by 100) $(M=14.33$, S.D. $=16.86)$.

(b) Attendance rate (coded as the aggregate days of student attendance divided by the sum of the aggregate days of student attendance and aggregate days of student absence multiplied by 100$)(M=$ 90.59, S.D. = 5.6). 
(c) Mobility rate (coded as the sum of the number of students transferred in and the number of students transferred out divided by the average daily enrolment multiplied by 100$)(M=37.26$, S.D. $=15.53)$.

(d) Student performance (coded as 1 for high student performers and 0 for low student performers) $(M=$ 0.52$, S.D. $=0.50)$.

Structural variables These variables relate to the structural characteristics of each school.

(a) School type (coded 1 for elementary and 0 for high school).

(b) Total enrollment (measured as a logarithm of total student enrolment in school) $(M=6.63, S . D .=$ 0.58).

(c) Class size (measured as a logarithm of mean class size for grades $K, 1,2,3$, and 8$)(M=3.24$, S.D. $=$ 0.19).

(d) Teacher/student ratio (coded as ratio of teachers to students in school) ( $M=0.07 ;$ S.D. $=0.07$ ).

(e) Clerical/teacher ratio (coded as ratio of clerical staff to teachers in school) $(M=0.53$, S.D. $=0.16$ ).

Race composition This variable, called race homogeneity, assesses the racial difference between the teacher and his or her colleagues and students. There is match when more than 50 per cent of the colleagues' race and students' race match that of the teacher (coded as 1 for match and 0 for mismatch of teacher's race with colleagues and students) $(M=0.35$, S.D. $=0.46)$.

School finances This variable measures the socio-economic status of each school by measuring the proportion of children receiving welfare (Ostroff, 1992). Socio-economic status (coded as the of students aged 5 to 17, whose families receive public aid, living in institutions for neglected or delinquent children, being supported in foster homes with public funds, or eligible to receive free or reduced lunches divided by total enrolment multiplied by 100$)(M=69.81$, S.D. $=27.37)$.

\section{Union related variables}

Union assistance (one item: $M=1.60, S . D .=0.80$ ) measured the frequency of assistance requested from the union as formulated by the researchers (i.e. 'How frequently do you make a request for assistance from the union?'; 1 = never, 5 = all of the time). Two variables signifying different kinds of participation in union activity were also included. Attendance at union meetings (one item: $M=2.26$. S.D. $=1.53$ ) was also developed by the researchers (i.e. "How often do you attend meetings of your union?'; 1 = never attend meetings, 5 = attend all meetings held) as was the measure of voting in union meetings (one 
item: $M=4.15$. S.D. = 1.27) (i.e. "How often do you vote in union elections?"; 1 = never, 5 = always). Both these variables are included in the model based on the findings by Kuruvilla et al. (1993), suggesting that increased information about the workings of the local union serves to reinforce member's loyalty to the union. ${ }^{\text {iv }}$ However, it is possible that the causality could be in both directions. Highly loyal individuals might perceive themselves to have more information than less loyal individuals since they trust the union (1) their information needs are lower and (2) they monitor the union's leadership much less. Nevertheless we rely on the results of Kuruvilla et al. (1993) in formulating our hypotheses.

\section{Analytical procedures}

The basic analytical strategy is to estimate the hypothesized causal model, then a revised causal model based on the results, and calculate the direct, indirect and total effects of the dispositional and contextual variables on union loyalty via path analysis.

The statistical techniques of multiple regression and LISREL were utilized in the analysis. Multiple regression was employed to assess and support the assumptions of linearity, additivity, model specification, multicollinearity, and homoscedasticity (Berry and Feldman, 1985).

The statistical technique of LISREL was used to estimate the causal model. LISREL VII produces a structural equation model and a measurement model (Jöreskog and Sörbom, 1988). The structural equation model specifies the hypothesized causal relationships among the concepts (latent constructs), whereas, the measurement model specifies a confirmatory factor analysis of hypothesized relationships between the latent (unobserved) constructs and the manifest (observed) variables.

One feature of LISREL is that it relaxes the assumptions that all variables have perfect reliability (no measurement error); that residuals are not correlated; and that the causal flow is recursive. There is general agreement that LISREL provides a more precise estimate of linear relationships among constructs than multiple regression (Bentler, 1980; Pedhazur, 1982). The first major advantage of LISREL derives from the added precision to the estimation of the causal model by correcting for attenuation in random measurement error of manifest variables. The second major advantage stems from the maximum likelihood method employed in LISREL, which produces both a statistical measure of goodness-of-fit and explained variance (R-square) of the model. As the coefficients can be interpreted as standardized regression coefficients, a path analysis (decomposed into direct, indirect, and total effects) can also be undertaken (Alwin and Hauser, 1975). 


\section{Results}

The following section presents two sets of results; first, the original hypothesized model, and second, the revised causal model.

\section{Hypothesized causal model}

Table 3 presents the LISREL results used to estimate the hypothesized model, which is shown in Figure 1. Nine variables as predicted by the model were found to have statistically significant net impacts on the first endogenous variable of job satisfaction (see column 1 of Table 3). The dispositional variables of positive and negative affectivity were found to have a significant impact of job satisfaction in the expected directions (Agho et al., 1993; Levin and Stokes, 1989), The job related variables of stress, routinization, promotional opportunity, job hazards, and distributive justice were significantly related to job satisfaction (Iverson and Roy, 1994: Mueller et al., 1994; Price and Mueller. 1986a). Amongst the contextual variables, attendance rate and school type were also found to effect job satisfaction. Job satisfaction is increased when teachers feel enthusiastic about life, have an opportunity for advancement, perceive they are treated fairly, teach students who frequently attend class, and who teach in elementary schools. In contrast, teachers display lower job satisfaction when they experience aversive emotional states, perceive the performance of their duties to be excessive, have repetitive work, and are exposed to harmful conditions. It can be seen from the results in Table 3 that 61 per cent of the variance in job satisfaction is explained by the variables in the model.

Consistent with previous research (Iverson and Roy, 1994; Mueller et al., 1994; Price and Mueller, 1986a: Williams and Hazer, 1986), job satisfaction was significantly related to organizational commitment (see column 3 of Table 3). Organizational commitment is increased when employees like their jobs. Fifty-two per cent of the variance in organizational commitment is explained by the variable of job satisfaction.

Union satisfaction was also determined by the union related variables of attendance at union meetings and voting in union elections (Kuruvilla et al., 1993) and job satisfaction (see column 5 of Table 3). Freeman and Medoff (1984) explain the finding of job satisfaction, whereby if unions are perceived to be instrumental in improving the working conditions of the members, then the job satisfaction of the members should also be enhanced. Individual member union satisfaction is increased when that 
individual teacher attend meetings, votes and is satisfied with his or her job. Thirteen per cent of the variance in union satisfaction is explained by the variables in the model.

The results support our hypothesized model in terms of the variance in union loyalty that is explained by the model. As can be seen in Table 3, the variables in the model explained 68 per cent of its variance (see column 7). Both organizational commitment and union satisfaction were significantly related to union loyalty (Barling et al., 1992). Teachers being loyal to the school system and satisfied with their union increases their loyalty to the union.

\begin{tabular}{|c|c|c|c|c|c|c|c|c|}
\hline \multirow[b]{2}{*}{ Determinants } & \multicolumn{2}{|c|}{$\begin{array}{l}\text { Job } \\
\text { satisfaction }\end{array}$} & \multicolumn{2}{|c|}{$\begin{array}{c}\text { Organizational } \\
\text { commitment }\end{array}$} & \multicolumn{2}{|c|}{$\begin{array}{c}\text { Union } \\
\text { satisfaction }\end{array}$} & \multicolumn{2}{|c|}{$\begin{array}{l}\text { Union } \\
\text { loyalty }\end{array}$} \\
\hline & & & & & & & (7) & (8) \\
\hline \multicolumn{9}{|l|}{ Demographic variables } \\
\hline Age & 0.06 & 0.06 & & & & & & \\
\hline Tenure & 0.00 & 0.00 & & & & & & \\
\hline Education & -0.05 & -0.05 & & & & & & \\
\hline Gender & -0.01 & -0.01 & & & & & & \\
\hline Teaching status & 0.05 & 0.05 & & & & & & \\
\hline Previous experience & -0.00 & -0.00 & & & & & & \\
\hline Kinship responsibility & 0.02 & 0.02 & & & & & & \\
\hline \multicolumn{9}{|l|}{ Dispositional variables } \\
\hline Positive affectivity & $0.17 \dagger$ & $0.17 \dagger$ & & & & & & \\
\hline Negative affectivity & $-0.15 \dagger$ & $-0.15 \dagger$ & & & & & & \\
\hline \multicolumn{9}{|l|}{ Job related variables } \\
\hline Stress & $-0.11 \dagger$ & $-0.11 \dagger$ & & & & & & \\
\hline Support & -0.02 & -0.02 & & & & & & \\
\hline Routinization & $-0.32 \dagger$ & $-0.32 \dagger$ & & & & & & \\
\hline Autonomy & 0.02 & 0.02 & & & & & & \\
\hline Pay & 0.02 & 0.02 & & & & & & \\
\hline Promotional opportunity & $0.19 \dagger$ & $0.19 \dagger$ & & & & & & \\
\hline Job security & 0.03 & 0.03 & & & & & & \\
\hline Job hazards & $-0.12 \dagger$ & $-0.12 \dagger$ & & & & & & \\
\hline Distributive justice & $0.08 \dagger$ & $0.08 \dagger$ & & & & & & \\
\hline \multicolumn{9}{|l|}{ Contextual variables } \\
\hline \multicolumn{9}{|l|}{ Nature and type of students } \\
\hline LEP students & -0.00 & -0.00 & & & & & & \\
\hline Attendance rate & $0.12 \dagger$ & $0.12 \uparrow$ & & & & & & \\
\hline Mobility rate & 0.04 & 0.04 & & & & & & \\
\hline Student performance & 0.04 & 0.04 & & & & & & \\
\hline \multicolumn{9}{|l|}{ Structural variables } \\
\hline School type & $0.12 \dagger$ & $0.12 \dagger$ & & & & & & \\
\hline Total enrolment & 0.00 & 0.00 & & & & & & \\
\hline Class size & 0.01 & 0.01 & & & & & & \\
\hline Teacher/student ratio & -0.06 & -0.06 & & & & & & \\
\hline Clerical/teacher ratio & 0.01 & 0.01 & & & & & & \\
\hline \multicolumn{9}{|l|}{ Racial composition } \\
\hline Race homogeneity & -0.02 & -0.04 & - & $0.12 \dagger$ & - & $0.09 \dagger$ & - & $0.07 \dagger$ \\
\hline School finances & & & & & & & & \\
\hline Socio-economic status & -0.03 & -0.03 & & & - & $-0.08 \dagger$ & & \\
\hline \multicolumn{9}{|l|}{ Union related variables } \\
\hline Union assistance & & & & & 0.02 & 0.01 & & \\
\hline Attendance at union meetings & & & & & $0.09 \dagger$ & $0.08+$ & & \\
\hline Voting in union elections & & & & & $0.15 \dagger$ & $0.15 \dagger$ & & \\
\hline \multicolumn{9}{|l|}{ Employee orientations } \\
\hline Job satisfaction & & & $0.72 \dagger$ & $0.72 \dagger$ & $0.28 \dagger$ & $0.27 \dagger$ & & \\
\hline Organizational commitment & & & & & & & $0.15 \dagger$ & $0.14 \dagger$ \\
\hline Union satisfaction & & & & & & & $0.78 \dagger$ & $0.77 \dagger$ \\
\hline$R^{2}$ & 0.61 & 0.61 & 0.52 & 0.54 & 0.13 & 0.14 & 0.68 & 0.68 \\
\hline
\end{tabular}




\section{The revised causal model}

Although the hypothesized causal model was largely supported, we proceeded to revise the model to better fit the data. Table 3 presents the LISREL results used to estimate the revised model (see the even numbered columns). The approach followed in fitting the LISREL model is consistent with the technique advanced by Iverson and Roy (1994). Mueller et al. (1994) and Wheaton (1987). First, all paths in the hypothesized model (see Figure 1) were retained, even if they were non-significant after analysis. Second, the hypothesized model was expanded by freeing up additional paths between variables that were indicated by the LISREL modification indices and considered to be theoretically plausible. According to Wheaton (1987, p. 125), the process of overfitting (e.g. extra parameters are fitted post hoc) is particularly useful when the fitting of extra parameters 'either indicate strong relationships with a plausible explanation or serendipitous possibilities that should be considered in future research'. This approach is particularly useful in exploratory research such as this, where the purpose is to explore the relationship of various antecedents of union loyalty.

For example, it was hypothesized that race homogeneity would have a positive effect on job satisfaction. The LISREL modification indices further identified that the path between race homogeneity and organizational commitment should also be estimated. It is theoretically plausible lo free up this path since individuals who are socially integrated would be expected to have greater loyalty to the organization. A number of other paths were also estimated in the revised model, and the results for those are discussed below.

A significant improvement in the goodness-of-fit index for the revised model $\left(x^{2}(94)=369.46\right.$, $p<0.001)$ compared to the hypothesized model $\left(x^{2}(98)=402.25, p<0.001\right)$ suggests that the revised model was better able to represent the relations in the sample data $\left(\Delta \mathbf{X}^{2}(4)=32.79 . p<0.001\right)$. Therefore it can be concluded that the goodness-of-fit for the revised model is a significant improvement over that of the hypothesized model.

In relation to the first endogenous variable of job satisfaction, no additional paths were estimated in the revised model (see column 2 of Table 3). The same nine hypothesized antecedent variables were found to have a significant net impact on job satisfaction. They comprised the dispositional variables of positive affectivity and negative affectivity, the job related variables of stress, routinization, promotional opportunity, job hazards, and distributive justice, and the contextual variables of attendance rate, and school type. Sixty-one percent of the variance in job satisfaction is explained by the variables in the model. 


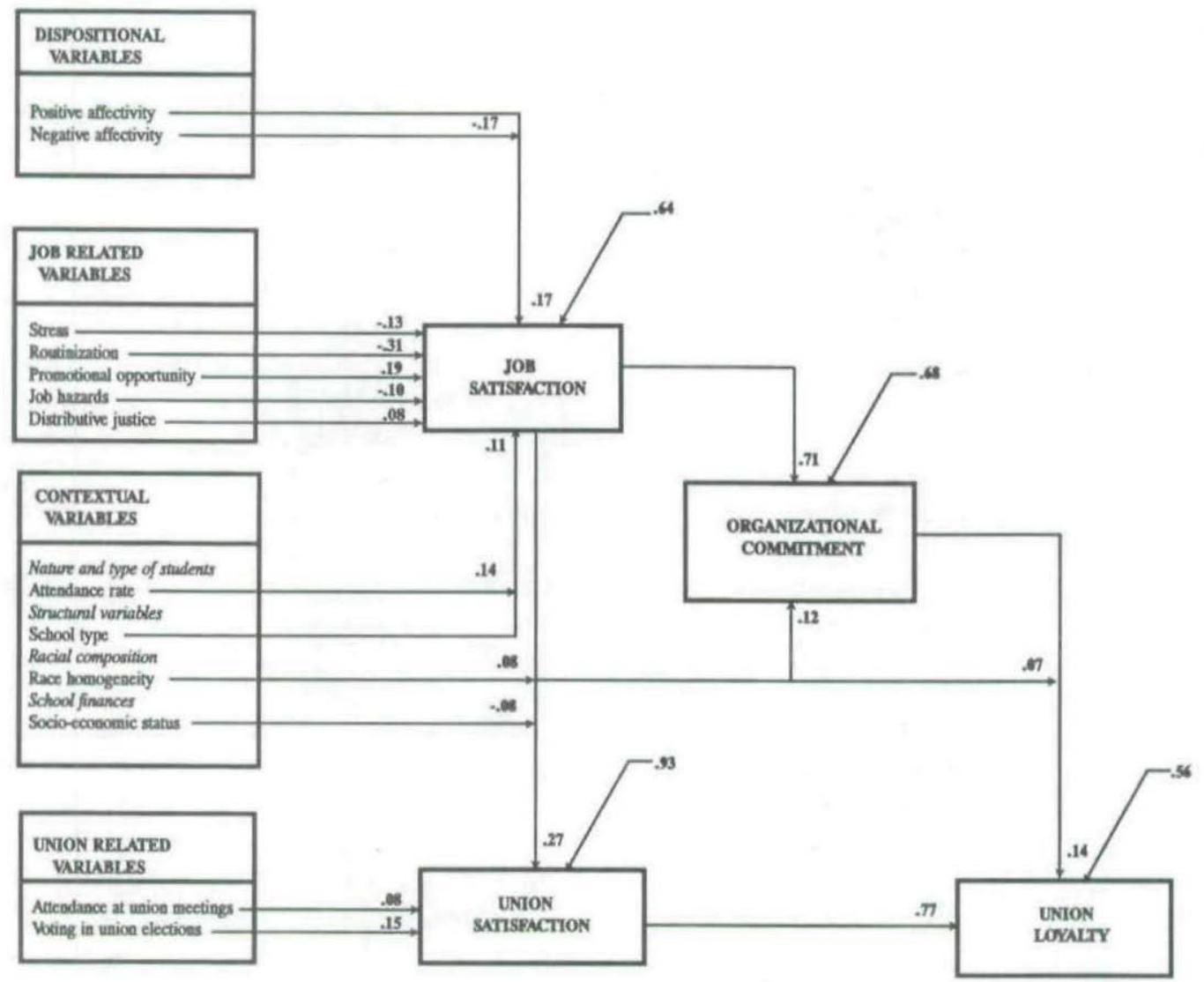

Figure 2. Simplified model of union loyalty

With regard to the second endogenous variable of organizational commitment, job satisfaction was the major predictor. However, the results also indicated that it would be worthwhile to estimate an additional antecedent path from race homogeneity lo organizational commitment. The results of this inclusion suggest (see column 4 of Table 3 ) that the lower the degree of racial difference (i.e. more homogenous populations of teachers, students and colleagues) the more likely teachers will be loyal to the school system. This result is consistent with those reported by Tsui et al. (1992), although as noted below, this result needs to be interpreted with some caution. Fifty-four per cent of the variance in organizational commitment is now explained by the two variables in the model.

Further revisions in the model indicated that in addition to attendance at union meetings and voting in union elections and job satisfaction (originally hypothesized), the contextual variables of race homogeneity and socio-economic status had effects on the third endogenous variable of union satisfaction (see column 6 of Table 3). Teachers who teach in schools with colleagues and students of similar race to themselves display greater satisfaction to the union. Also, teachers from lower socio- 
economic status schools exhibit higher union satisfaction. Fourteen per cent of the variance in union satisfaction was explained by the variables in the model.

The dependent variable, union loyalty, had 68 per cent of its variance explained by variables in the model (see column 8 of Table 3). The revised model did not result in any increase in the percentage of variance explained in union loyalty. Nevertheless, apart from organizational commitment and union satisfaction, racial homogeneity was a significant predictor of union loyalty in the revised model.

Teachers display greater loyalty to the union when there is less racial difference between their colleagues, students and themselves.

The simplified (revised) causal model based on the above discussion is presented in Figure 2. This model retains only those variables significantly related to union loyalty. All paths were statistically significant and in the expected directions.

Path analysis

Given that freeing up the paths of several variables provided an overall increase in the fit of the revised model over the originally hypothesized model, we estimate the direct and indirect impacts of these variables on union loyalty.

The simplified causal model (see Figure 2), decomposed into direct, indirect and total effects of the determinants of union loyalty is contained in Table 4. In relation to the significant total effects of the variables on union loyalty, the rank order of the variables is as follows: union satisfaction (0.77), job satisfaction (0.31), race homogeneity (0.15), organizational commitment (0.14), voting in union elections (0.12), routinization (-0.09), positive affectivity (0.06), negative affectivity $(-0.06)$, promotional opportunity (0.06), socio-economic status $(-0.06)$, attendance at union meetings (0.06), stress $(-0.04)$, attendance rate (0.04), job hazards (-0.03), distributive justice (0.03), and school type (0.03).

Table 4 yields several interesting results. The dispositional variables are indirectly related to union loyalty via job satisfaction, organizational commitment and union satisfaction. In terms of the contextual variables several interesting relationships can also be found. Attendance rate and school type (i.e. whether teachers taught in elementary or secondary schools) are also indirectly related to union loyalty via job satisfaction, organizational commitment, and union satisfaction. Most surprisingly, race homogeneity has pervasive impacts on the endogenous variables in the model. It had a direct effect on union loyalty, and an indirect effect through organizational commitment and union satisfaction. Finally, socio-economic status had an indirect impact on union loyalty through union satisfaction. 
As expected, job satisfaction is related to union loyalty only via organizational commitment and union satisfaction, without any direct effect, contrary to much of previous research that has hypothesized a direct effect (e.g. Fullagar and Barling, 1989). As proposed, organizational commitment and union satisfaction are directly related to union loyalty (Barling et al., 1992; Gallagher and Clark, 1989).

Apart from the results for the dispositional and contextual variables, the results for the other exogenous variables performed as posited and were consistent with previous research, although we do not focus on these results in detail. For example, we found support for the impact of union participation (Kuruvilla et al., 1993), and for the effects of the job related variables such as stress, routinization, promotional opportunity, job hazards, and distributive justice, consistent with much of previous research (e.g. Barling et al.. 1992; Deery et al., 1994). However, these variables were included as controls to facilitate the examination of our individual disposition and contextual variables on union loyalty.

\section{Discussion}

The purpose of this paper was to explore the impact of individual dispositions and contextual variables on union loyalty, controlling for the effects of other determinants (i.e. demographics, job related, and union related variables) found in previous research. The results indicate general support for the inclusion of dispositional and contextual variables in models of union commitment, specifically union loyalty. The individual dispositions of positive and negative affectivity and the contextual variables of attendance rate, school type, race homogeneity and socio-economic status had significant total causal effects on union loyalty, Moreover, the results suggest that the exclusion of individual dispositions and contextual variables could lead to misspecification of commitment models (e.g. Berry and Feldman, 1985). The inclusion of contextual variables also have the advantage of eliminating biases such as common variance, which occurs when both the endogenous and exogenous variables measure attitudes, rather than objective data (Podsakoff and Organ, 1986). 


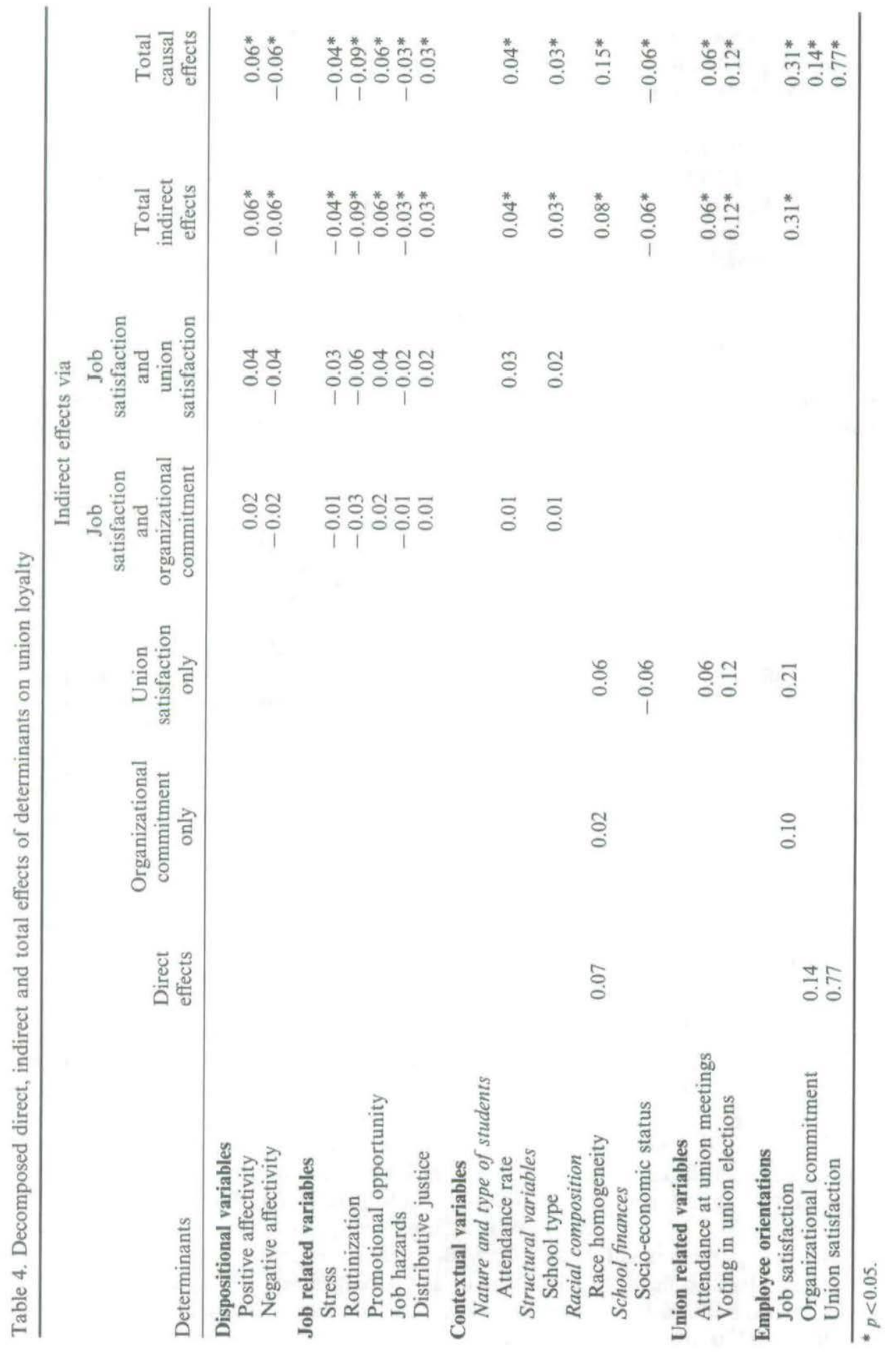


Clearly, the finding that union satisfaction and organizational commitment were significant predictors of union loyalty underscores the reality in the industrial relations of school districts in this sample i.e., unions have a considerable 'voice' in decision making (Freeman and Medoff, 1984), and more importantly, are seen by members as being instrumental in making improvements affecting their working lives (Barling et al., 1992). The strong relationship between union satisfaction and union loyalty is particularly noteworthy in this regard (Kuruvilla et al., 1993) ${ }^{v}$. This result suggests the possibility articulated by several researchers that dual commitment (simultaneous commitment to both the organization and union) may be influenced by a harmonious industrial relations climate (e.g. Gordon and Ladd, 1990).

The results for the dispositional variables have important implications for future research on union commitment. Union members with the personality traits of being enthusiastic, interested, friendly, and active (high positive affectivity) (Watson, Clark and Tellegen, 1984) are more likely to be loyal to the union, whereas those with the personality traits of being afraid, jittery, angry and ashamed (high negative affectivity) (Watson et al., 1984) are more likely not to be loyal to the union. There is a lesson here for unions. Unions have tended to focus much attention on working conditions and socialization in terms of gaining the commitment of members (Barling et al., 1992). Nevertheless, our results indicate that if these are 'stand alone' strategies they may have limited effects given that individuals enter with different propensities to be loyal to the union. These findings suggest the value of union sponsored self development programs to enable members to gain a better understanding of one's self and attitudes. These programs have often been undertaken by organizations in the belief that it improves overall organizational effectiveness. These results imply that there is some transferability to the union situation as well.

In terms of the contextual variables, an important finding is the direct and indirect effects of race homogeneity on union loyalty. Note that race homogeneity was related to organizational commitment, and union satisfaction and through these variables, to union loyalty. Note also that race homogeneity also evidenced a direct link to union loyalty. Amongst our contextual variables, this variable has the strongest effect on union loyalty. As with other findings (Tsui et al., 1992), this result underscores the fact that more homogenous populations have increased commitment to both employers and unions. This finding is curious given the current push towards increased diversity in educational institutions and workplaces in the U.S. We caution the reader about making strong 
conclusions from this result. We are constrained by lack of adequate data to further examine the factors underlying the result for this variable. Nevertheless, in an attempt to understand this result better, we examined the means in respect of our endogenous variables for different racial groups. We found that minority teachers evidenced higher means relative to white teachers on union loyalty, union satisfaction, organizational commitment, and job satisfaction. ${ }^{\text {vi }}$ This finding is consistent with Messick and Mackie's (1989) examination of the underlying processes of intergroup relations, whereby the integration of minority members into majority-dominated settings would be expected to lead to the lowering of majority members' attitudes to the organization and union.

Support for this view can also be seen in the fact that the majority of students in this district are from minority groups, with 59 per cent being African-American, 26 per cent Hispanic, 3 per cent Asian, and 10 per cent being from other diverse races, compared to 12 per cent of students being White. Moreover, minority teachers (i.e. Hispanic and African-American) tend to teach in schools with students and colleagues of the same race as themselves, as compared to White teachers who are more likely to teach in multi-racial schools ${ }^{\text {vii. }}$. Therefore, our tentative explanation for this result is that it reflects the tensions associated with the demographic change in U.S. labor markets. In this context, we refer to the relatively recent efforts by the union and the school district to increasingly diversify its recruitment to include more teachers from minority groups. Tsui et al. (1992) note that there are basically three responses to the tensions created from increased heterogeneity: fight, flight, and psychological withdrawal. As legal and labor market constraints prohibit or restrict to some degree the fight or flight responses, it is probable that teachers would engage in the psychological withdrawal response. If that is the case, then this result is more congruous with the explanations drawn from social identity theory (Hogg and Abrams, 1988).

It is apparent that additional data and theoretical frameworks are required to investigate this issue more clearly. Based on this preliminary investigation, however, our results merely suggest the importance of the race variable. Future research may wish to examine the different access of racial groups to positions of power and status within the school districts in this region. If, for example, rewards are limited and resources scarce, majority group members may perceive their ability to access these eroded by the presence of minorities (regardless of the 'objective reality'). In unions that successfully negotiate for their workers' well-being, would the presence of minorities have a less negative effect? These are the types of issues that warrant additional attention in the literature.

Of the other contextual variables, the level of socio-economic status was found to have the second most important impact on the degree to which teachers are loyal to the union. Schools from low 
socio-economic status districts tend to be disadvantaged and as such, lack resources and adequate physical facilities which limit student performance (Coleman et al., 1966). Since these issues are the subject of collective bargaining, and the union is actively involved in these decisions, the connection between this variable and union loyalty appear obvious.

Attendance rate also had a significant indirect influence on union loyalty via job satisfaction. Clearly, the number of students attending classes affects the job satisfaction of teachers (as student attendance had a significant positive correlation with student performance) and through that affects union loyalty. Elementary teachers were found to exhibit greater loyalty to the union relative to high school teachers, Elementary schools and high schools suffer from fundamentally different problems. Elementary schools, for example, primarily suffer from overcrowding problems, whereas, high schools suffer from problems of students lacking basic skills, student discipline, alcoholism, drugs, violence, teenage pregnancies, inadequate programs for gifted children, and overcrowded classrooms (MLS, 1985). Our data does not allow us to explain how exactly the conditions in these two types of schools differ, but our results clearly reflect the fact that the union must have a different orientation in relation to different types of problems in elementary and high schools.

In general, our results indicate that unions should not exclude the influence of individual dispositions and contextual factors in promoting the loyalty of their members. In this study, we have examined several contextual variables that particularly impinge on the working lives of teachers, such as the attendance rate of students and the socio-economic background of the students that they teach. It is possible that we have not measured other more important contextual factors, such as per pupil expenditure.

However, the point we wish to make is that it is important for researchers to include appropriate dispositional and contextual variables in all studies of union commitment, given the significant relationships that we have found in our results. In particular, dispositional variables such as positive and negative affectivity are universalistic, germane to individuals, not just school teachers. Other dispositional variables (e.g. personality traits such as internal or external locus of control) which have shown to be important in studies of job satisfaction, must also be investigated in the union commitment literature.

Although we have examined only a few contextual variables in this study, our results raise the possibility that contextual variables may be more important than many other categories of variables in explaining union member attitudes. It is also possible that the impact of contextual variables on member attitudes may vary from setting to setting as well. Although several general contextual variables have 
been examined in the organizational literature, such as structure, or technology, or environment, the challenge for researchers is to measure both general contextual variables, but also specific contextual variables pertinent to the sample studied.

In sum, the potential of individual dispositions and contextual variables as determinants of union loyalty remain to be explored, and we suggest they warrant further attention in the literature. Perhaps one step in the right direction is to develop a more coherent conceptual taxonomy (e.g. Arvey et al., 1991) of the relationship between dispositional and contextual variables and job and union satisfaction and union loyalty. Such a conceptual scheme may be necessary to guide future commitment research to provide greater insight into the process by which members become attitudinally and behaviorally attached to unions.

\section{References}

Agho, O. A., Mueller, C. W. and Price, J. L. (199.1). 'Determinants of employee job satisfaction: An empirical lest of a causal model', Human Relations. 46. 1007-1027.

Agho. O. A., Mueller. C. W. and Price. J. L. (1992) 'Discriminant validity of measures of job satisfaction, positive affectivity and negative affectivity'. Journal of Occupational and Organizational Psychology, 65, 185-196.

Alwin, D. F and Hauser. R M. (1975). 'The decomposition of effects in path analysis', American Sociological Review. 40. 37-47.

Anderson. J, C. and Gerbing, D. W. (1988). 'Structural equation modelling in practice: A review and recommended two step approach'. Psychological Bulletin, 103, 411423.

Angle. H L and Perry. J- L. (1986). "Dual commitment and labor management relation climates'. Academy of Management Journal. 29. 31-50.

Arvey. R. D., Caner. G. W. and Buerkley. D. K (1991). *Job satisfaction: Dispositional and situational influences' In: Cooper. C L. and Robertson, I. T. (Eds) International Review of Industrial and Organisational Psychology. Vol. 6, John Wiley \& Sons, New York, pp. 359-583.

Baggozzi, R. P. and Yi. Y. (1988). 'On the evaluation of structural equation models'. Academy of Marketing Science, $16,74-94$.

Barling, J., Fullagar, C. and Kelloway, E K. (1992). The Union and its Members A Psychological Approach. Oxford University Press, New York.

Bentler, P. M, (1990). 'Comparative fit indexes in structural models', Psychological Bulletin, 107, 238246.

Bentler, P. M. (1980). 'Multivariate analysis with latent variables: Causal modelling', Annual Review of Psychology, 31, 419-555.

Berry, W. and Feldman, S. (1985). Multiple Regression in Practice. Sage University Paper series on quantitative applications in the social sciences, Sage Publications, Beverly Hills, CA. 
Blegen, M. A., Mueller, C. W. and Price, J. L. (1988). 'Measurement of kinship responsibility for organizational research', Journal of Applied Psychology. 73, 402-409.

Brayfield, A. H. and Rothe, H. F. (1951). 'An index of job satisfaction", Journal of Applied Psychology, 35, 307-311.

Brief. A. P., Burke. M. J., George, J. M., Robinson, B. S. and Webster, J. (1988). 'Should negative affectivity remain an unmeasured variable in the study of job stress?' Journal of Applied Psychology, 73, 193-198.

Caplan, R. D., Cobb, S., French. J. R. P., Jr., Harrison, R. V. and Pinneau, S. R., Jr. (1975). Job Demands and Worker Health: Main Effects and Occupational Differences, U.S. Government Printing Office. Washington., D.C.

Coleman, J., Campbell, E., Hobson, C, McPartland. J., Mood. A., Weinfield. F. and York, R. (1966). Equality of Educational Opportunity, Government Printing Office, Washington, DC.

Cortina. J. M. (1993). "What is coefficient alpha? An examination of theory and applications". Journal of Applied Psychology, 78 (1), 98-104.

Crisci, P. E. and Shadow, M, (1988). 'Concessionary pay bargaining in education'. Government Union Review, 9 (4). 1-39.

Dawson. S., Poynter, P. and Stevens, D. (1983). 'How to secure an effective health and safety program at work'. Omega. U, 443-446.

Deery, S. J., Iverson, R, D. and Erwin, P. J. (1992). 'Dual commitment: A parallel models approach'. Paper presented at the 9th World Congress of the International Industrial Relations Association, Sydney, Australia.

Deery, S. J., Iverson, R. D. and Erwin, P. J. (1994). 'Predicting organizational and union commitment: The effect of industrial relations climate', British Journal of Industrial Relations, 32, 559-575.

Fishbein. M, and Ajzen, 1, (1975) Belief, Attitude, Intention, and Behavior: An Introduction to Theory and Research. Addison-Wesley. Reading, M.A.

Freeman. R. B, and Medoff, J. L. (1984). What Do Unions Do? Basic Books, New York.

Fullagar, C. and Barling, J. (1989). 'A longitudinal test of the model of the antecedents and consequences of union loyalty', Journal of Applied Psychology, 74, 213-227.

Fullagar, C. and Barling, J. (1991). 'Predictors and outcomes of different patterns of organizational and union loyalty'. Journal of Occupational Psychology, 64, 129-143.

Gallagher, D. G. and Clark, P. F. (1989). 'Research on union commitment: Implications for labor'. Labor Studies Journal, 14. 52-71.

Geisert, G. (1992), "Principal leadership in American school reform, Government Union Review, 13 (4), 1-15.

Gordon, M. E., Beauvais. L. L. and Ladd, R. T. (1984). The job satisfaction and union commitment of unionized engineers'. Industrial and Labor Relations Review, 43, 359-370.

Gordon, M. E. and Ladd, R. T. (1990). 'Dual allegiance: Renewal, reconsideration, and recantation'. Personnel Psychology, 43, 37-69. 
Gordon, M. E., Philpot. J, W., Burt, R. E., Thompson, C, A. and Spiller. W. E. (1980). "Commitment to the union: Development of a measure and an examination of its correlates', Journal of Applied Psychology, 65, 479499.

Gottfredson, G. D. and Gottfredson, D. C. (1985). Victimization in Schools, Plenum Press, New York.

Gujarati, D. (1978). Basic Econometrics, McGraw-Hill, New York.

Hammer, T. and Wazeter, D. (1993). 'Dimensions of local union effectiveness', Industrial and Labor Relations Review, 46 (2), 302-319.

Herzberg, F. (1968). Work and the Nature of Man, Granada, London.

Hogg, M. A. and Abrams, D. (1988). Social Identification: A Social Psychology of Intergroup Relations and Group Processes, Routledge, New York.

House, J. S. (1981). Work Stress and Social Support, Addison-Wesley, Reading, MA.

Iverson, R. D. (1992). 'Employee intent to stay: An empirical test of a revision of the Price and Mueller model'. Unpublished doctoral dissertation. The University of lowa.

Iverson, R. D., Olekalns, M. and Erwin, P. J. (1994). 'Affectivity, organisational stressors and absenteeism: A causal model of burnout and it's consequences'. Paper presented at the 54th Annual Academy of Management Meetings, Dallas, Texas.

Iverson, R. D., and Roy, P. (1994). 'A causal model of behavioural commitment: Evidence from a study of Australian blue-collar employees'. Journal of Management, 20 (1), 15-41.

Jöreskog, K. B. and Sörbom, D. (1988). LISREL VII: Analysis of Linear Structural Relationships by the Method of Maximum Likelihood. Scientific Software, Morrisville, IN.

Judge, T. A. (1993). 'Does affective disposition moderate the relationship between job satisfaction and voluntary turnover?" Journal of Applied Psychology, 78. 395-401.

Judge. T. A. and Hulin, C. L. (1993). 'Job satisfaction as a reflection of disposition. A multiple source causal analysis', Organizational Behavior and Human Decision Processes, 56, 388-421.

Kahn. R. L., Wolfe. D. M., Quinn. R. P., Snoek. J. D. and Rosenthal. R. A. (1964). Organizational Stress: Studies in Role Conflict and Ambiguity, Wiley, New York.

Katz, H. C. and Kochan, T. (1991). Collective Bargaining and Industrial Relations, McGraw-Hill Series in Management, New York.

Kuruvilla, S., Gallagher. D. G. and Wetzel. K. (1993). The development of union attitudes: Evidence from Sweden and Canada'. Industrial and Labor Relations Review, 46 (3). 499-514.

Kuruvilla, S. and Iverson, R. D. (1993). 'A confirmatory factor analysis of union commitment in Australia', Journal of Industrial Relations, 35 (3), 436-452.

Lawler, E. E. (1971). Pay and Organizational Effectiveness, McGraw-Hill, New York. 
Levin, I. and Stokes, J. P. (1989). 'Dispositional approach to job satisfaction: Role of negative affectivity'. Journal of Applied Psychology, 74, 752-758.

Locke. E. A. (1976). 'Nature and causes of job satisfaction", In: Dunnette, M. D. (Ed.) Handbook of Industrial and Organizational Psychology, 1297-1349, Rand McNally, Chicago.

Martin. T. N. (1979). 'A contextual model of employee turnover intentions', Academy of Management Journal, 22, 313-231.

Messick, D. M. and Mackie. D. M. (1989). 'Intergroup relations'. In: Rosenzweig, M. R. and Porter, L. W. (Eds) Annual Review of Psychology, Vol. 40, Annual Reviews, Palo Alto CA, pp. 45-81. Metropolitan Life Survey (1989). Preparing Schools for the 1990s, Louis Harris and Associates, New York. Metropolitan Life Survey (1985). Strengthening the Profession, Louis Harris and Associates, New York.

Mueller. C. W., Boyer. E. M., Price. J. L. and Iverson, R. D. (1994). ‘Employee attachment and non-coercive conditions of work: The case of Dental Hygienists', Work and Occupations, 21 (2), 179-212.

Mowday, R. T., Porter, L. W. and Steers, R. M. (1982). Employee-Organization Linkages: The Psychology of Commitment, Absenteeism and Turnover. Academic Press, New York.

Oldham, G. R., Kulik. C. T., Stepina. L. P. and Ambrose, M. L. (1986). 'Relations between situational factors and the comparative referents used by employees'. Academy of Management Journal, 29, 599-608.

Ostroff, C. (1992). 'The relationship between satisfaction, attitudes, and performance: An organizational level analysis'. Journal of Applied Psychology, 77, 963-974.

Parker, R. N. and Fenwick, R. (1983). The Pareto Curve and its utility for open-ended income distributions in survey research'. Social Forces, 61, 872-885.

Pedhazur, E. J. (1982). Multiple Regression in Behavioural Research, CBS College Publishing, New York.

Podsakoff. P. and Organ, D. (1986). 'Self-reports in organizational research: Problems and prospects', Journal of Managements, 12, 531-544.

Porter, L. W., Steers, R. M., Mowday, R. T. and Boulian, P. V. (1974). 'Organizational commitment, job satisfaction and turnover among psychiatric technicians'. Journal of Applied Psychology, 59, 603-609.

Price, J. L. and Mueller. C. W. (1986a). Absenteeism and Turnover of Hospital Employees, JAI Press, Greenwich, CT.

Price, J. L. and Mueller, C. W. (1986b). Handbook of Organizational Measurements, Pitman, Marshfield, MA.

Price, J. L. and Mueller, C. W. (1981). Professional Turnover: The Case of Nurses, SP Medical and Scientific, New York.

Pulakos, E. D. and Schmitt, N. (1983). 'A longitudinal study of advance model approach for the prediction of job satisfaction of new employees', Journal of Applied Psychology, 68, 307-312.

Register, C. A. and Grimes, P. (1991). 'Collective bargaining, teachers, and student achievement' Journal of Labour Research, 12 (2), 99-109. 
Rizzo, J. R., House, R. J. and Litzman, S. I. (1970). 'Role conflict and ambiguity in complex organisations'. Administrative Science Quarterly, 15, 150-163.

Schneider, B. (1987). The people make the place'. Personnel Psychology, 40, 437-453.

Smith. S. K. (1989). The teacher union contract: a constraint on downsizing in the public school'. Journal of Collective Negotiations in the Public Sector, 18 (2), 229-239.

Staw, B. M. and Ross. J. (1985). 'Stability in the midst of change: A dispositional approach to job attitudes'. Journal of Applied Psychology, 70, 469-480.

Tetrick, L. E. and LaRocco, J. M. (1987). 'Understanding, prediction, and control as moderators of the relationships between perceived stress, satisfaction, and psychological well-being', Journal of Applied Psychology, 72, 538-543.

Tsui, A. S., Egan, T. and O'Reilly, C., III. (1992). 'Being different: Relational demography and organizational attachment', Administrative Science Quarterly, 37, 549-579.

Tsui, A. S. and O'Reilly, C, III. (1989). 'Beyond simple demographic effects: The importance of relational demography in superior-subordinate dyads', Academy of Management Journal, 32, 402-423.

Tucker, W. (1991). 'More money', Forbes, 148 (13), 184-185. USA Research (1984). Meeting the Challenge of a Nation at Risk: The National Commission on Excellence in Education, USA Research, Cambridge: Mass.

Watson. D., Pennebaker, J. W. and Folger, R. (1987). 'Beyond negative affectivity: Measuring stress and satisfaction in the workplace', Journal of Organizational Behavior Management, 8, 141-157.

Watson, D. and Clark. L. A. (1984). 'Negative affectivity: The disposition to experience aversive emotional states'. Psychological Bulletin, 96, 465-490.

Watson. D., Clark, L. A. and Tellegen, A. (1984). 'Cross-cultural convergence in the structure of mood: A Japanese replication and a comparison with US findings'. Journal of Applied and Social Psychology, 47, 127-144.

Wheaton, B. (1987). 'Assessment of fit in overidentified models with latent variables', Sociological Methods and Research, 16, 116-154.

Williams, L. J. and Hazer, J. T. (1986). 'Antecedents and consequences of satisfaction and commitment in turnover models: A reanalysis using latent variable structural equation methods', Journal of Applied Psychology, 71, 219-231.

Wishnick, Y. S. and Wishnick, K. T. (1993). 'Collective bargaining and educational reform: Establishing a labor management partnership', Journal of Collective Negotiations in the Public Sector, 22 (1), 1-11. 


\section{i}

${ }^{1}$ Table 5. Goodness-of-fit alternate factor model specifications for union commitment*

\begin{tabular}{lrccccccc}
\hline Model & $x^{2}$ & $d f$ & $p<0$. & GFI & AGFI & RMSR & NFI & PFI \\
\hline Null & 2951.26 & 55 & 000 & 0.442 & 0.331 & 0.331 & - & - \\
1 factor & 465.70 & 44 & 000 & 0.897 & 0.845 & 0.065 & 0.842 & 0.803 \\
2 factor & 300.98 & 43 & 000 & 0.933 & 0.898 & 0.055 & 0.898 & 0.870 \\
4 factor & 113.86 & 38 & 000 & 0.976 & 0.958 & 0.035 & 0.961 & 0.944 \\
\hline
\end{tabular}

- Four-factor model was found to be the best fitting model (i.e. the four-factor model was a significant improvement in fit over two-factor model: $\chi^{2}(5)=187.12, p<0.05$ ). The union commitment items in this paper were also subjected to an exploratory factor analysis. The factor analysis provided support for four factors, consistent with the confirmatory factor analysis and the results of Gordon et al. (1980). Union loyalty was found to be the dominant factor, explaining 40 per cent of the total variance. The other factors, responsibility to the union, willingness to work for the union and beliefs in unionism explained 13 per cent, 8 per cent and 7 per cent of the variance, respectively.

ii Although the scales of positive affectivity, routinization, autonomy, promotional opportunity, and job hazards had alphas lower than 0.70, they are included in the analysis for several reasons. First, Cortina (1993) notes that as '...alpha is very much a function of the number of items in a scale...it must be interpreted with the number of items in mind' (p. 102). In light of Cortina's (1993) article, we examined the inter-item and item-total correlations for these variables. Both of these correlations were found to be higher than 0.30 for the five scales. We therefore consider the scales to display acceptable reliability (given that all were measured by three-items). Moreover, when examined in combination with the evidence of the factor analysis, the fact that the variables behave as expected, the fact that the model provides a good indicator of fit, and the fact that the results in terms of these variables are generally consistent with results of several other studies that have used these variables (e.g. Agho et al., 1992. 1993,; Oldham et al., 1986; Price and Mueller, 1986a; Tetrick and LaRocco, 1987), the issue of low reliability does not cause a problem in this analysis.

iii See page 559.

iv Researchers (e.g. Kuruvilla et al., 1993) distinguish between high or active (e.g. being elected a union officer) and low or passive (e.g. voting in elections and attendance at meetings) union participation. However, as only 2.3 per cent $(n-19)$ of members were elected officials in this study we could not employ this measure of active participation.

${ }^{v}$ Union satisfaction and union loyalty demonstrated discriminant validity, although they had a zero-order correlation of 0.78 .

vii

${ }^{5}$ Table 6. Means on endogenous variables and race homogeneity by race*

\begin{tabular}{lccccc}
\hline Variable & White & Hispanic & African-American & Asian & Other \\
\hline Union loyalty & 3.01 & 3.11 & 3.42 & 3.54 & 3.40 \\
Union satisfaction & 3.00 & 3.05 & 3.32 & 3.43 & 3.20 \\
Organizational commitment & 3.26 & 3.54 & 3.60 & 3.73 & 3.75 \\
Job satisfaction & 4.04 & 4.18 & 4.14 & 4.28 & 4.16 \\
Race homogeneity & 0.10 & 0.28 & 0.74 & 0.00 & 0.00 \\
$N$ & 390 & 51 & 209 & 23 & 15 \\
\hline
\end{tabular}

* ANOVA results indicated that African-American teachers reported significantly higher union loyalty, union satisfaction and organizational commitment than White teachers.

$\dagger$ Race homogeneity ranges from 1 match to 0 mismatch. 